This article was downloaded by: [Purdue University]

On: 13 March 2015, At: 09:48

Publisher: Routledge

Informa Ltd Registered in England and Wales Registered Number: 1072954

Registered office: Mortimer House, 37-41 Mortimer Street, London W1T

3J H, UK

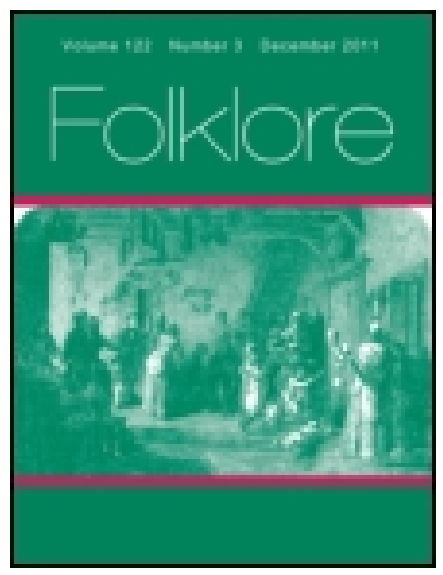

\title{
Folklore
}

Publication details, including instructions for authors and subscription information:

http:// www. tandfonline.com/loi/ rfol20

\section{First Foot in Lancashire}

E. Skeffington Thompson

Published online: 14 Feb 2012.

To cite this article: E. Skeffington Thompson (1900) First Foot in Lancashire, Folklore, 11:2, 220-220, DOI: 10.1080/0015587X.1900.9720534

To link to this article: http:// dx. doi. org/ 10.1080/0015587X.1900.9720534

\section{PLEASE SCROLL DOWN FOR ARTICLE}

Taylor \& Francis makes every effort to ensure the accuracy of all the information (the "Content") contained in the publications on our platform. However, Taylor \& Francis, our agents, and our licensors make no representations or warranties whatsoever as to the accuracy, completeness, or suitability for any purpose of the Content. Any opinions and views expressed in this publication are the opinions and views of the authors, and are not the views of or endorsed by Taylor \& Francis. The accuracy of the Content should not be relied upon and should be independently verified with primary sources of information. Taylor and Francis shall not be liable for any losses, actions, claims, proceedings, demands, costs, expenses, damages, and other liabilities whatsoever or howsoever caused arising directly or indirectly in connection with, in relation to or arising out of the use of the Content.

This article may be used for research, teaching, and private study purposes. Any substantial or systematic reproduction, redistribution, reselling, loan, sub-licensing, systematic supply, or distribution in any form to anyone is 
expressly forbidden. Terms $\&$ Conditions of access and use can be found at http://www.tandfonline.com/page/terms-and-conditions 


\section{Sunwise Processions.}

In the Rev. S. Baring-Gould's Book of the iVest the following is recorded:

"There was a churchyard cross at Manaton [Devonshire]. The Rev. C. Carwithen, who was rector, found that the people carried a coffin thrice round it, the way of the sun, at a funeral; although he preached against the usage as superstitious, they persisted in doing so. One night he broke up the cross and removed and concealed the fragments. It is a pity that the cross did not fall on and break his stupid head."-Vol. i., p. 39.

My daughter Mabel tells me that somewhat less than twenty years ago she was present at a wedding in the parish church of Lustnau, near Tübingen, which belongs to the Lutheran body. $\Lambda$ the conclusion of the service the wedding party, including the guests invited to the marriage feast, walked round the stone altar and the crucifix behind it. They passed from the west to the north and thence to the east and then on to the south. The pastor's wife said it was the custom, but gave no explanation of. its meaning.

These practices seem to be survivals of sun-worship, adapted to Christianity.

EDWard Peacock.

\section{First Foot in Lancashirs.}

My sister and I were staying with relations in Lancashire on New Year's Day, 1900, and about five o'clock a heavy step came up into the upper hall, off which the bedrooms opened, and a man's voice called out "Good new year to you!" We found that this is a very old Lancashire custom called "First foot in the house." The man who entered the house we were in, has been the first to enter it for eleven years, and he always gets ten shillings in gold.

He must be a man with dark hair, and not flat feet; and he must come in at the hall door, go up.all through the halls and cry out, "Good new year to you," three times, and go out at the back door.

\section{E. Skeffington Thompson.}

[The Rev. E. W. Clarke notes both dark hair and high instep occur at Hull, Yorkshire.-G. L. G.] 